\title{
The Expression of Self-Identity and the Internet
}

\author{
Ass. Prof. Dr Bilge Gürsoy \\ Marmara University, Faculty of Communication \\ Istanbul, Turkey \\ bilge41@gmail.com
}

\section{Doi:10.5901/jesr.2013.v3n7p477}

\begin{abstract}
This article examines and analyzes how gypsies express their identity on the internet, as opposed to real life. Throughout history, Gypsies, who were seen as "the different" have established tight connections with the countries and became component of the country they lived. By the help of internet, they are not "the different" or "the other" anymore and they became the citizens of McLuhan's global village. Gypsy identity and advocacy use and focus on internet as a community platform. They express themselves comfortably and more people understand, share their problems. One of their web addresses is cingeneyiz. org (We are Gypsies. org), in which they say their first aim is to solve the problem of incomprehension between Gypsies and people living together with them. First part of this study analyses communication and self-expression of Gypsies through new technologies by giving cingeneyiz.org example, how they get in touch and organize, and the importance of hypertext, the links and e-mails are analyzed. In the second part of the article, the analysis of in- depth interview with ten gypsies (five male, five female) on their self identity is made.
\end{abstract}

Keywords: Internet, self-expression, identity, gypsy.

\section{Gypsy Identity Out Of Web and In Web}

\subsection{Identity}

All people derive particular identities from their roles in society, the groups they belong to, and their personal characteristics. An identity is "the set of meanings that define who one is when one is occupant of a particular role in society, a member of a particular group, or claims particular characteristics that identify him or her as a unique person" (Burke, Stets, 2009: 3). People develop social identities based on their nationality, ethnicity, religion and social roles. For example "I am Turkish; I am a Buddhist; I am a teacher" are examples of social identities. They give us a feeling of place and position in the world. "Without them, most of us would feel like loose marbles rolling around in a chaotic universe. Because of the importance of social identities, most people feel their group is distinctive and special" (Tavris, Wade, 2001:407). According to Adrian Marsh, "History is identity, the primary means of acknowledging sameness, membership of the group and difference from others. It is always established, whether in part or wholly, through the sharing of a narrative of origins, of journeys of migration, or anti-migratory narratives of autochthony, and of 'present' as related directly to 'before' (...)" (Marsh, 2007: 22)

\begin{abstract}
In modern societies, many social identities are possible. People often face the dilemma of balancing their ethnic identity, a close identification with their religious or ethnic group, with acculturation, identification with the dominant culture (...) as groups develop a strong ethnic identity; they often reject the name that was imposed on them by the majority culture and choose their own. The Eskimos of Canada are now called the Inuit, their own name for themselves, and the Sioux are now the Lakota (Tavris, Wade, 2001:407, 408).
\end{abstract}

According to Angus Fraser (1995), Gypsies are "a people of Europe", the word such as "Gypsy" were given to them by outsiders (1-2). From a general point of view, "identity conflict" constitutes a central problem for Gypsies living in different cultures as in Turkey. "Roman" in Turkey and "Roma" or "Rroma" in Europe has recently been used for defining Gypsies. Roman refers to an international recognition and usage, names like "Çingene" (Turkish), "Tsigane" (French), "Zigeuner" (German) and "Gitano" (Spanish) highlight the local recognitions. Gypsies have taken different names since their first appearance in history, and they represent a defined culture. Although Gypsies travelled long distances they embraced and preserved their own language, while migrating and lived in different cultures. These migrations resulted in 
a series of changes and accent differences in Gypsy language, yet it still survives to a degree enough to meet the demands of daily language today. The language is significant for Gypsies, since it is a defining and distinguishing factor for recognising identity. On the other hand, scholars who studied Gypsies' origin could not explain how Romany language changed from Indian origin to Europe languages.

It is possible to date the relationship between Gypsies and Turkish society back to very old times, since Gypsies first came to Iran after leaving India and then they spread all over the world in three branches. One of these branches crossed to Europe over Anatolia (Kolukirik, 2007:31). According to Melih Duygulu, Gypsies settled in Anatolia coming from Caucasians and Persia. He sees three main groups among Gypsies: Nomads, semi-nomads and settled Gypsies. Nomads travel from village to village or village to city according to season. Although semi-nomads are settled in periphery of cities, they move according to seasonal labor (Duygulu, 2006: 22).

\title{
1.2 The Gypsy Image Out of Web
}

The definition of "Gypsy" in The Oxford English Dictionary, $2^{\text {nd }}$ edition, 1989 is: A member of wandering race (by themselves called Romany), of Hindu origin, which first appeared in England about the beginning of the $16^{\text {th }}$ century, and was then believed to have come from Egypt (Fraser, 1995: 2). According to Anne Sutherland who studied American Gypsies in 1968, there are misconceptions about the Gypsies. For example the name "Gypsy" is used as metaphor for freedom; and Gypsies as thieves (1986: xi).

In the Department of Sociology in Ege University, Turkey, an 'Attribute Constellation Study' is made in 2005. The group of 61 people, constituting 48 females and 13 males from the third and fourth year of undergraduate studies were given a questionnaire about the associations of the names Gypsy and Roman. As a result the name Gypsy was perceived as negative, while the name Roman was perceived as positive. The adjectives with highest frequency closest to the centre of the Gypsy graphic were "thief", "nomad", "entertainer" and "fortune teller"; whereas the corresponding adjectives in the Romani graphic included "musician" and "entertainment". In this sense, entertainer was used to define both the Gypsy and Romani. The adjectives "thief" and "dirty", which were used to define the Gypsy, were less frequent in the Romani graphic and were further from the centre (Kolukirik, 2005:52-71).

It is not wrong to say that prejudices are directed to Gypsies and the word "Gypsy".

\begin{abstract}
A prejudice consists of negative stereotype and a strong, unreasonable dislike or hatred of a group or its individual members. Feelings of prejudice violate the spirit of critical thinking because they resist rational argument and evidence (...) Prejudice is a universal human experience because it has so many sources: evolutionary, psychological, social and cultural (Tavris, Wade, 2001:424-425).
\end{abstract}

According to Suat Kolukirik, the common characteristic of the negative images and prejudices about Gypsies is their reference to what is different between Gypsies and the remainder of societies in which they live. These historically produced images and prejudices have a common point that is the representation Gypsies as strangers. Kolukirik underlines, the perceived otherness of Gypsies should not be regarded as a characteristic peculiar only to Turkish society. According to Kolukirik, it is possible to come across prejudices about Gypsies in all the societies they exist as well as in fictive works, legends, anecdotes, films and laws. The main problem arises from the adjectives, legends, and anecdotes produced by the mechanism of prejudice. This puts the Gypsy identity and image under pressure and affects interaction between Gypsies and non-Gypsies. "Prejudices about Gypsies include adjectives that may possibly be seen in all groups of society. Yet, it is always Gypsies who are seen as scapegoats" (Kolukirik, 2007: 37).

There are many books about Gypsies written by "non Gypsies". Some reflect sympathy to Gypsies. For example in his book Gypsies Opre Roma, Jan Yoors wrote that "...Romans life is an endless improvisation" and also he wrote that a Roman man called Piti La Kaliako looked very poor, but everybody called him a millionaire because he had spent one million (2005:17, 20, 21). According to Duygulu Gypsies do not have written culture, because their philosophy is 'living today' without past and future. Most of the themes of their songs are love, separation, money. Gypsies manage to sing the saddest songs in a cheerful way with a lively music (Duygulu 2006: 90-92).

\subsubsection{Gypsy Web Page}

According to Anne Sutherland, the Gypsies have faced dramatically technological changes since they left India and began wending their way into Western Europe.

To most anthropologists, technological change without social change seems inconceivable; yet the descriptions of the 
most economic and social behaviour from the earliest accounts to the present day, from Russia, Greece, North Africa, and Western Europe to North and South America are easily recognizable as Gypsy (Sutherland ,1986: 3).

In 2005 Çingeneyiz.org was founded to represent Gypsies at every level and it is the voice of Gypsies. It was prepared by a group of intellectual gypsies and volunteers including non-gypsies. They do not have direct or indirect benefits for themselves. Then radio and online television is added. Çingeneyiz.org aims to overcome foreignness between Gypsies and non-Gypsies and prejudices targeting Gypsies. They believe that the only way to reach this goal is to create a communication channel.

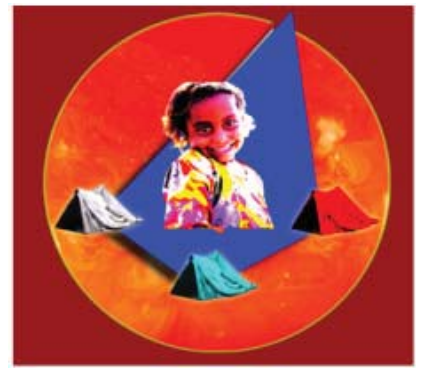

The Gypsies' Web Page in Turkey welcomes you with a flag. There are four basic elements in the flag of the web page. These are: three Gypsy tents; the Roma girl figure, the sun and a blue square. The Gypsy tents symbolises a figure which has been a living space for Gypsies as commercial nomads during long nomadic times. The tents are used with three colours in the flag with the aim of explaining that all differences of the humanity are included within the Gypsy society. There are Gypsies as commercial nomads all over the world. People who are from different races, ethnicities and nations and who speak different languages can be a part of the Gypsy society. The Roma girl figure symbolises the Gypsy woman who is at the centre of the Gypsy community and who represents the Gypsy community with the moral power she has. Gypsy woman has individual and collective power. The blue square symbolises long ways Gypsies have left behind. The square is blue because blue is the colour of our planet. The Sun which appears on background of the flag is the future of Gypsies and all the humanity. The sun brings life to all living beings in the nature and it is also a source of hope for the future. The sun symbol makes us remember the words of Halide Edip Adıvar, a famous Turkish writer, "When the night gets the darkest, the sunshine is closer."

There are several dictionaries in the web page, prepared and translated by several authors. The web page, also prepared a campaign to collect words. Examples of some words;

maskare means in between

bitchavava means to send

gosto means woman

kanro means difficult

Romanes Canes: Do you know Roman (Laxo dialect)

Cingeneyiz tv only includes photographs, video archives and information about Gypsy history or activities. The first aim of the web-site called cingeneyiz.org, is to solve the problem of incomprehension between Gypsies and people living together with Gypsies.

\subsubsection{How Gypsies define themselves in their web page?}

In their web page, Gypsies define themselves as written below.

We are the children of the commercial nomads. The ancestors of Gypsies have produced baskets, sieves, metal objects and tins to sell to other people. Our ancestors could not find any other possibility like agriculture or stockbreeding, because they were deprived of herds and wide lands. Actually, this is the only difference between Gypsies and the others. There is only one distinctive characteristic of Gypsies: They have lived on with commercial nomads for thousands of years. So they ask the question: Then what is the reason of this fear and the sense of strangeness against us? The answer is: The history of Gypsies is also the history of human being. So we have to start to tell our history from the period that there was no division between occupations. 'Thousands of years, human beings were living under similar conditions. Gathering and hunting were the only occupations. Human beings were living 
through hunting wild animals and gathering various plants. (...) In this period, shepherd tribes needed wide grasslands. They have become armed to protect their grasslands and herds against the attacks of the other tribes. On the other hand, some tribes continued gathering and hunting. But these occupations could not be done as easily as before, because shepherd tribes started to protect their grasslands through combating. Because of the pressure of the nearby shepherd tribes, these people were forced to do a different occupation: Commercial nomads. They started to sell their craft products, in exchange for the products of shepherd tribes. So these tribes found a new way to survive. Our base occupations like making baskets, ironing, sieving and tinning are the keepsakes of those days. (...) The division between the shepherds and the commercial nomads is the reason of today's distinction as gaco-muul-geben and Çingene.

They protest being "untouchable" in their Web Page. The lines below are from Gypsies web-page in Turkey and it is an example of expressing his/her self freely through internet.

Yes, I am untouchable! Evil, treachery and humiliation cannot touch me anymore, owing to vitalizing pains we have witnessed. People looking to our shabby shoes cannot break my heart. Since we have had lives like death for thousands of years, no one can touch to our divine freedom. I am an untouchable. I am proud of what I am. Everybody must know. I am a gypsy!

These lines underline the protest to being called "untouchables" through history. On the other hand, it seems that this kind of "humiliation" ended. In Turkey, according to Mustafa Aksu, the author of cingeneyiz.org, Gypsies see themselves as a component of Turkey. All the citizens of Turkish Republic are the members of the Turkish nation. The citizenship brings rights and obligations to all citizens and Gypsies have these rights and are responsible to fulfil these obligations. Aksu thinks Gypsies evaluate themselves as equal citizens of Turkey, not a minority.

Through out history, Gypsies have established tight connections with the countries they lived in. For example they adopt the religion of the countries in which they live. Today it is possible to observe that Gypsies attempt to get organised in accordance with the democratic development of the countries in which they live. However, according to Kolukirik, Gypsies, who possibly form the poorest population of the country in which they reside, seem to fail to display a strong attitude concerning this matter (Kolukirik, 2007: 31).

\subsection{Hypertexts In Gypsy Web Page}

According to Marshall Mcluhan "The new electronic interdependence recreates the world in the image of global village" (2011: 36). The Gypsy web page seems to connect Gypsies to each other from all over the world. In this connection "hypertexts" play an important role. "Hypertext" is a term coined by Theodor H. Nelson in the 1960s. It has been used most successfully by the interactive multimedia computer systems that came into commercial use in the early 1990s. According to Barthes; this text is a galaxy of signifiers. Like Barthes, Michel Foucault conceives of text in terms of network and links (Landow, 2006: 2). George P. Landow uses the terms hypermedia and hypertext interchangeably.

In Gypsy Web page, there are examples of these mentioned "Hypertexts" that are given below.

Ahirkapi Roman Orkestar (http://www.ahirkapiroman.com/index.asp)

European Roma Rights Center (http://www.errc.org)

Voice of West Trakya (www.iskecem.de)

Edirne Roman Association (http://www.edrom.org.tr),

Flamenco House (http://www.simonajovic.com)

Everyonegroup(http://www.everyonegroup.com)

Güney Brothers (http://grupguneykardesler.npage.de/index.html),

Institute of Earth Art and Architecture, (http://kaliji.eu/default.aspx)

Roma of Hungary (http://www.amarodrom.hu),

Manchester Romani Project (http://www.simonajovic.com),

Roman Istanbul (http://www.romanistanbul.org),

Some of the links such as "Ahirkapi Roman" includes video and sound as well as photographs and texts. The link called "European Roma Rights Centre" includes many links such as research, news-events, human rights education, resource centre, and donation. For example Human Rights Education activities aim first and foremost to empower Romani activists. It aims to raise human rights awareness among the Romani community. It also aims to empower Romani individuals to fight for equality through the knowledge and experience in human rights and international law human rights law instruments. 


\title{
2. Self Identity-Interviews With The Gypsies
}

In this section there are two kinds of interviews. In the first part, examples of interviews that are in Gypsy web page are given. In the second part, my interviews with five women, five men Gypsies are analysed.

\subsection{Interviews in "Gypsy web page"}

\subsubsection{Interview with Mustafa Aksu}

Mustafa Aksu is a Gypsy intellectual, retired bureaucrat. In his interview made in 18 May 2011, he attracts our attention to discrimination of Gypsies in Turkish Dictionaries. According to Aksu, the word "Çingene" (meaning Gypsy in Turkish) were identified falsely in all Turkish dictionaries (except one) published by various foundation in Turkey. Gypsies were identified as piker, rapacious, randy, and cheeky in the dictionaries. Some adjectives like "covetous, dirty, shameless" were added to some of the dictionaries too as the identification of Gypsy. In addition expressions related to Gypsies like "Çingene pembesi (Gypsy pink), Çingene parasi (Gypsy money), Çingene dügünü (Gypsy wedding), Çingene kavgasi (Gypsy fight), Çingenelik (Being Gypsy)..." were written with their explanation including a discriminative mentality full of prejudices in the dictionaries. Aksu and some other intellectuals tried to delete these definitions. After long termed legal struggle, some text including discriminative speech was deleted from the dictionaries. In 2004, Presidency of Turkish Linguistic Society declared corrections to ministries, related foundations. It was a great success for Gypsies.

According to Aksu, Gypsy is not an adjective. Gypsy is the name of ethnical identity. Claiming someone to be Gypsy is not a revilement. On the other hand, Aksu thinks many Gypsy origin scholars, bureaucrats, musicians still prefer to hide their origin. For example when Aksu announced names of twenty seven famous Gypsies, three of them got angry with him and they made statements on press that they were not Gypsies.

\subsubsection{Interview with Judith Okely}

Judith Okey is Emeritus Professor of Social Anthropology. Her books include: The Traveller-Gypsies (1982), Anthropology and Autobiography (1992) Own or Other Culture (1996). Her comments about the "Gypsy web page" are as follows.

\begin{abstract}
Meanwhile what I have been able to access and read looks wonderful. There is a superb mix of different voices and groupings...I am delighted with the aim of international solidarity through links with different groups across the world. (...) Thus your website gives wonderful scope for the celebration of ALL persons and groups with some common associations.

Your website also has some heart-rending personal life histories of suffering and political injustice. (...) Gypsy children I knew may not have been schooled but they were EDUCATED in the broader aspects of the world.

Finally, I also, as part of your web declares, recognise the power, brilliance and political intelligence of Gypsy women, so it would be good to have this made more visible in the organisational 'leaders' whom you portray in your photograph.
\end{abstract}

\subsection{Interviews with Gypsies Out of Web}

I have made interviews with ten gypsies (five male, five female) living in Istanbul, Sariyer in February 2012. Their age's ranges from 30 to 55, eight of them (five women, three men) are graduated from primary schools and two men continued to secondary schools. All of them sell flowers, paper napkins, bottled water and all of them work in the recycling industry at different times. Collecting and selling rubbish is one of their occupations. They live on collecting and selling paper, different sorts of plastics and all sorts of metal to recycling firms. Two men sometimes work as house painters and clean gardens (cutting bushes, unwanted branches). The other men also played "drums" at special occasions. All of them seemed to be interested in music and they had "musicians" in their families. In addition most of their children wanted to be musician in future. Gypsy musicians generally go to play in the bars of Taksim or in the fish restaurants of Kumkapi. They say, older men in their families know the art of horseshoe-making but today as a result of the replacement of horses by cars there is not so much work to be done.

These Romans do not use internet and they do not know anything about Gypsy web page. But they think their children may know. Two of them said their children had computers. They give importance to their children's education. But they complain about school segregation. In Sariyer-Istanbul one of the primary school is full of Gypsy children and 
non Gypsy families do not want to send their children to that school. It is interesting that Gypsy families also do not want to send their children to that school. Because they think the education quality of that school seems poor.

These Gypsies do not look like the intellectual Gypsies of the web, because they prefer to be called "Roman" instead of Gypsy. As mentioned before, Gypsies of the web prefer to be called "Gypsy."

\section{No Watches- Rhythms of nature}

The Gypsies who made interview with me had no watches (Only one man had a watch). This can be explained by the difference between "monochronic culture" and "polychronic culture."

Canada and the United States along with northern European nations are monochronic cultures. In these cultures time is organised sequentially; schedules and deadlines are valued over people. "Monochronic people" do one thing at a time, they give the job first priority, they place high value on private property (...) On the other hand, in polychromic cultures, time is organised horizontally; people tend to do several things at once and value relationships over schedules. "Polychronic people" do many things at once, they give people first priority, they borrow and lend things often (...) South of Europe, South of America and Africa are polychronic cultures. According to Edward Hall, a culture's way of organizing time is not arbitrary. It stems from the culture's economic system, social organization, political history and ecology. The monochromic structure of time emerged as a result of Industry Revolution in England. Thousands of people began working in factories and assembly lines, their efforts had to become coordinated. In rural economies work is based on the rhythms of nature. Hall (1983) worked with many Hopi. He found that they were amused by the "white" government's compulsive schedules for buildings roads and houses. According to Hopi, unlike the maturing of a sheep or the ripening corn, building a house has no inherent timetable. "The Hopi did care about completing their planting and religious ceremonies, activities that indeed had to be done 'on time' - nature's time, not human time" (Tavris, Wade, 2001: 403405).

It seems that Romans are polychronic people because they follow nature's time. In addition they do multiple activities at the same time. For example a Roman woman sells flower, feeds the baby, and makes conversation at the same time. It can be said that their family relations are more important than their work and they like to borrow things from each other.

\section{Individualist or Collectivist?}

Who are you? "I am ..." According to Tavris and Wade (2001), your response to this question will be influenced by your cultural background. In individualist cultures, the independence of the individual often takes precedence over the needs of the group, and self is often defined as a collection of personality traits. In collectivist cultures, group harmony takes precedence over the wishes of the individual, and self is defined in the context of relationships and the community ("I am the son of a farmer..."). In collectivist cultures, the boundaries between the self and other people are more flexible and the strongest bond is usually not between husband and wife but between parent and child or siblings (Tavris, Wade, 2001: 405-406).

It can be said that my interviews with the Gypsies and observations showed that, Gypsies belong to collectivist culture and also they have strong ethnic identity. They seem to have strong bonds between them and their children. This bond seems stronger than husband-wife bonds. In addition they call themselves as "Romans".

\section{Conclusion: Internet, is it a promise?}

We generally pass by Gypsies on the streets without noticing them, but sometimes we stop and buy flowers from them or we listen to their beautiful Gypsy music at night when they play in or in front of some bars, restaurants. Unfortunately, the problems of employment, education and housing increase the poverty of Gypsies and the distance between Gypsies and the other parts of our society. Intellectual Gypsies prepared the Gypsy web page and this web page seems to help to solve the problems of the Gypsies. On the other hand, most of the Gypsies that I have do not have any computers. But two of them said their children had computers and it seems that Gypsies give importance to their children's education. It can be said that the education level of the Gypsies is increasing. Intellectual Gypsies underline that "they are proud of being Gypsy" in their web page. On the other hand, poorly educated Gypsies, mostly seen on the streets as flower sellers etc. prefer to be called as "Romans" and they do not like to be called as Gypsy. It can be said that, there is a relationship between high education and internet usage, and more importantly there is a relation between high education 
and higher "self esteem".

Although most of the Gypsies do not have any computers, internet is still a promise because; many Gypsies managed to have higher education and managed to prepare a web page. The necessary information about laws and human rights, activities, entertainments and most importantly their feelings are learned and shared by Gypsies and nonGypsies through internet. These kinds of web pages seem to manage to break down prejudices among Gypsies and non-Gypsies. More importantly the web page does not only pull attention to human rights but also make non-Gypsies to think about their duties towards Gypsies.

\section{References}

Burke, J. Peter, Stets, E. Jan (2009). "Agency and Social Structure", Identity Theory. Oxford: Oxford University Press, p. 3-18.

Duygulu, Melih (2006). Gypsy Music in Turkey. Istanbul: Pan Publish.

Fraser, Angus (1995). The Gypsies. USA: Blackwell Publishing.

George P. Landow (2006). Hypertext 3.0 Critical Theory and New Media in Era of Globalisation. USA: The John Hopkins University Press.

Kolukirik, Suat (2005). "The Gypsy Image and Bias in the Turkish Society", Sociological Research Journal. Volume 8, No: 2, p. 52-71.

Kolukirik, Suat (2007). "The Perception of Gypsies In Turkish Society", Perceptions, Roma Rights Quarterly No 3, 2007, European Rome Rights Centre, p. 31-37.

Marsh, Adrian (2007). "Research and the Many Representations of Romani Identity", Perceptions, Roma Rights Quarterly, № 3, 2007, European Rome Rights Center, p.17-31.

McLuhan, Marshall (2011). The Gutenberg Galaxy. Canada: University of Toronto Press.

Sutherland, Anne (1986). The Hidden Americans. USA: Waveland Press Inc.

Tavris, C., Wade, C. (2001). Psychology in Perspective. New Jersey: Prentice Hall Inc.

Yoors, Jan (2005). Gypsies Opre Roma. Istanbul: Idefix Publish. 